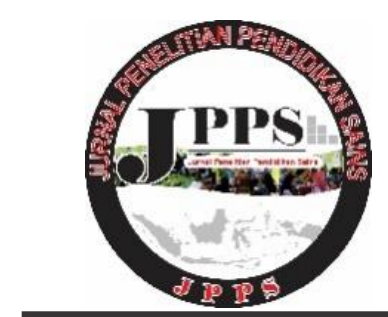

JPPS (Jurnal Penelitian Pendidikan Sains)

p-ISSN: 2089-1776

e-ISSN: 2549-1597

Volume 9, No.1, November 2019

https://journal.unesa.ac.id/index.php/jpps/index

\title{
COMPARATIVE STUDY: MISCONCEPTIONS ON PHOTOSYNTHESIS AND RESPIRATION CONCEPTS FROM PAST TO THE PRESENT
}

\author{
Puji Jayanti ${ }^{* 1}$ dan Yuni Sri Rahayu ${ }^{2}$ \\ ${ }^{1,2}$ Department of Science Education, Postgraduated Program, Universitas Negeri Surabaya \\ Indonesia \\ Email: puji.18027@mhs.unesa.ac.id
}

\begin{abstract}
This study aimed to compare the past misconception problems in photosynthesis and respiration topics with the present cases in Indonesia. This descriptive study was undertaken to mainly describe the misconception on science learning from the past to the present times. Misconception test was used as the research instrument that was given to Indonesian students from four provinces namely East Java, South Sulawesi, South Sumatra, and Middle Kalimantan. This study used an experiment conducted in 1996, of which they were further compared with the present literatures about misconception in photosynthesis and respiration, including the data of pre-service teacher class obtained from 2010 to 2017 . Results found that there was a similar misconception from 1996 to 2017 about photosynthesis and respiration. There was an indication that misconception in photosynthesis and respiration was not solved properly. This study suggested that the results could be used as an awareness for teachers in accordance with numbers of misconceptions in photosynthesis and respiration that have existed since long ago. Some actions were needed to overcome the misconceptions. One of the effort is by increasing students scientific reasoning skills. By increasing of students' scientific reasoning skills, students will be able to interpret the information they got and using some evidence that related to evaluated the information truth. But the further research is needed to develop learning devices to train students' scientific reasoning skills.
\end{abstract}

Keywords: Misconception, photosynthesis, respiration, comparative study 


\section{INTRODUCTION}

When students learn new materials in class, most of them already have a prior knowledge or preconception about the materials in their mind (Suma et al. 2017). Such pre-conception might change along with the learning process. The student's conception of particular information taught within classroom activities can be very different from the true information given by the teacher. Their incompatible conception with an accepted scientific concept is familiarly known as misconception. Many studies on misconception have been already conducted to understand the existing misconception in biology (Queloz, et al. 2017). Moreover, studies on misconception in biology have been variously undertaken in many topics such as human respiratory system (Silvia \& Almaeda, 2017), photosynthesis (Parker et al, 2012; Anjarsari, 2018; Urey, 2018), and various organ systems and mechanism in animal and plant. Student's misconception can be a dominant learning obstacle in science learning so that it should be solved effectively.

Student's misconception in photosynthesis and respiration system has been widely researched during times to times (Svandova, 2014). Parker et al. (2012) state that misconception in photosynthesis might occur because many students lack both basic understanding of the role of photosynthesis in plant metabolism and the ability to reason with scientific principles when learning new knowledge. Svandova (2017) conveys that misconception in photosynthesis is in connection with respiration topic in which the reaction of both photosynthesis and respiration is slightly similar. In other words, respiration is known as the reverse reaction of photosynthesis. Svandova (2017) also portrays that most textbooks and teachers treat these two reactions equally, therefore, they often forget to note that the reactions take place in different cells and are influenced by dissimilar enzymes.

This study focuses on identifying misconception in photosynthesis and respiration under the assumption that misconception in photosynthesis and respiration is interrelated. In this study, the researchers aim to compare the misconception in photosynthesis and respiration from the past found in a related-experiment conducted and in many literatures with those in the present times. The comparison helps to understand whether the misconception of the past was similar with the present times or not.

Teacher's knowledge about student's common misconceptions in science learning can be very useful to overcome the misconception problems. Even so, students are often confronted with difficulties in changing their misconceptions because their conception has already made sense for them (Sadler \& Sonnert, 2016).

Misconceptions can occur if the process of assimilating prior knowledge before acquiring the true knowledge in the classroom cannot be incorporated (Bayuni et al., 2018). Researcher speculates that teacher's understanding can be one of the factors that contribute to student's misconception. To reveal whether the teacher's understanding in photosynthesis and respiration is correct, his understanding is necessary to be tested. In this study, the misconception diagnostic test is not only given to the students but also to the pre-service teachers that study in science education at postgraduated program to show their understanding in photosynthesis and respiration from 2010 until 2017 along with describing the pre-service teachers' misconception from times to times.

\section{METHOD}

\section{Data Collection Procedure for Students' Misconception in 1996 (The Past)}

Data were collected in September after the new education period or school year began. In this period, most senior students in Junior High School had studied science for slightly more than two years. The class III curriculum was not considered in the study, rather, the information of what the students at class III had learnt in their first two years at the school. The national curriculum statement and the text books published by the Department of Education and Culture were used to define concepts or topics to be included in the tests that would be further administered. Overviewing the text books gave the researcher opportunity to know the maximum level of difficulty or complexity of the questions that would be created.

The researcher with her team conducted a survey in four provinces namely East Java, South Sulawesi, South Sumatra, and Middle Kalimantan, of which four schools of each province were chosen for 
the researcher to visit. To make the obtained information based on students' difficulties more comprehensive, it was decided to select one school from each of the following categories: a wellequipped public school, a private school, an urban public school within half to one hour drive from the city center, and an isolated public school. The classes to be observed could be at any level and were to be selected after cosultation with the school principal. The team believed that it would be informative to sample teaching styles and strategies at all levels to assist the diagnosis of possible cause of learning difficulties. The team also felt that any observation should be systematic and able to lead to written record.

No formal schedule was prepared for conducting students' interviews. It was planned after the test had been administered for four to five random students who completed the biology test. Their completed paper test in biology would be used by one team member whose expertise was in biology as a basis for a group discussion on how the students arrived at the answers for each question. The group discussion was conducted between 45 minutes and one hour.

Data Collection Procedure for Pre-Service Teachers' Misconception since 2010 to 2017 (The Present)

Misconception diagnostic test on photosynthesis and respiration topics was given to the pre-service teachers majoring science education at postgraduated program. Many of them had already worked as science teachers at different schools. The misconception diagnostic test was given to the preservice teachers enrolled in different education periods from 2010 to 2017.

Comparative Study about the Past and Present Misconceptions

Data obtained from the misconception diagnostic test that was carried out in 1996 were compared with the present literatures of Indonesian junior high school students' misconception in photosynthesis and respiration. The comparison was performed to describe whether the students' misconception in the past was similar to that of the present times.

\section{RESULT AND DISCUSSION}

Misconception on the Difference between
Photosynthesis and Respiration
Puji Jayanti, et al

In 1996, misconception diagnostic test was given to junior high school students. In accordance with the administered questions, question 1 was about the difference between photosynthesis and respiration. Six statements related to both photosynthesis and respiration were presented. Students were asked to choose the statements which one was in connection with photosynthesis (1a) and respiration (1b). Table 1 shows the result of 1(a) and 1(b).

Table 1. Students' Answer for Question 1(a) and 1 (b)

\begin{tabular}{lcc}
\hline School Scores & $\begin{array}{c}\text { Correct } \\
\text { Answer }\end{array}$ & $\begin{array}{l}\text { Acceptable } \\
\text { Reason }\end{array}$ \\
\hline $\begin{array}{l}\text { The highest school } \\
\text { score }\end{array}$ & $49 \%$ & $25 \%$ \\
$\begin{array}{l}\text { The lowest school } \\
\text { score }\end{array}$ & $0 \%$ & $0 \%$ \\
$\begin{array}{l}\text { The average school } \\
\text { score }\end{array}$ & $9 \%$ & $9 \%$ \\
\hline
\end{tabular}

In this question, the students were allowed to choose more than one answer. The average score of the correct answer for question 1a was $9 \%$, which meant that most students did not know about photosynthesis. Moreover, Table 2 depicts the average proportion of students' answers for each alternatives in question 1(a).

Table 2. Students' Answer for Each Alternatives in Question 1(a)

\begin{tabular}{cc}
\hline Alternatives & Proportion \\
\hline A & $48 \%$ \\
B & $61 \%$ \\
C & $20 \%$ \\
D & $51 \%$ \\
E & $42 \%$ \\
F & $30 \%$ \\
\hline
\end{tabular}

All alternatives were chosen by the students for many reasons. $48 \%$ of the students said that photosynthesis produced oxygen but the plant did not use the oxygen. Students thought that the emitted oxygen from the photosynthesis process was only used by animals and not by the plants themselves for respiration. In addition, since the question had a little different wording to distinguish between 'at night times' and 'in the dark', some students interpreted the two to be similar to one another. However, during the interviews, this point was raised and almost all students thought that light had to come from the sun in order for photosynthesis to take place. Even the question had been written clearly, students still experienced wrong understanding about the concept of light used in the photosynthesis.

Question 1b showed a low student understanding of respiration. The highest school score was $25 \%$, the lowest school score was $0 \%$, and the average school score was $9 \%$. In short, students understood that both photosynthesis and respiration were similar. Table 3 shows the average proportion of students' alternative answers for question $1 b$. 
Table 3. Students' Answer for Each Alternatives in Question 1(b)

\begin{tabular}{cc}
\hline Alternatives & Proportion \\
\hline A & $48 \%$ \\
B & $16 \%$ \\
C & $41 \%$ \\
D & $36 \%$ \\
E & $41 \%$ \\
F & $41 \%$ \\
\hline
\end{tabular}

The reasonable answer for respiration were A, D, and $\mathrm{F}$. The alternative $\mathrm{D}$ was not quite right because respiration did not produce energy, but changed energy from one form to another. Alternative $\mathrm{C}$ became a correct answer for both respiration and photosynthesis. The high proportion of those who chose E might be due to many students' confusion in understanding both respiration and photosynthesis in plants. In respiration and photosynthesis, the energy change was not the same. Therefore, the students had a very low understanding in differentiating respiration and photosynthesis.

Svandova (2014) published a report about Misconception in photosynthesis end respiration. Based on her research, students mistook photosynthesis for plant respiration. They thought that plant produced oxygen throughout the day and that respiration took place only in leaves performed in specific organs only.

\section{Misconception on Plant's and Animal's Respiration System}

In fact, all living things including plants and animals respired in the same way. In the respiration process, sugar or other nutrients were broken down into $\mathrm{CO}_{2}$ and $\mathrm{H}_{2} \mathrm{O}$ by the assist of $\mathrm{O}_{2}$. Question 2 asked the students about the difference between respiration in plant and animal. The purpose of this question was to find the level of students' understanding about respiration process.

Students were required to give their opinion about respiration in both plants and animals. If they thought there was no significant difference between respiration in plant and animal, they would write same. On the contrary, they would write different for the existing significant difference. A short explanation also was required to show how their decision was made. Table 4 portrays an analysis of students' opinions along with their supporting reason.

Table 4. Students' Answer for Question 2

\begin{tabular}{lll}
\hline School Scores & \multicolumn{2}{l}{ Percentage of Student Give } \\
\cline { 2 - 3 } & $\begin{array}{l}\text { Correct } \\
\text { Answer }\end{array}$ & $\begin{array}{l}\text { Acceptable } \\
\text { Reason }\end{array}$ \\
\hline $\begin{array}{l}\text { The highest school } \\
\text { score }\end{array}$ & $45 \%$ & $36 \%$ \\
$\begin{array}{l}\text { The lowest school } \\
\text { score } \\
\text { The average school } \\
\text { score }\end{array}$ & $23 \%$ & $0 \%$ \\
\hline
\end{tabular}

In accordance to Table 4, students who answered correctly varied from $23 \%$ to $45 \%$ with the acceptable reason ranging from $0 \%-36 \%$. By referring to the condition, majority of students had problems in understanding concepts. Only 30\% from 624 students gave a correct answer, however, few of them could give an acceptable reason to show how the decision was made. In some schools, no students were able to support their answer with an acceptable explanation. The results suggested that students simply guessed the answer when coming to the concept they did not understand. Further, Table 5 shows an insight about the level of misconseptions depicted by the following examples of students' reasoning.

\section{Table 5. Students' Reasons for Question 2}

\begin{tabular}{cl}
\hline No & \multicolumn{1}{c}{ Explanation } \\
\hline 1 & $\begin{array}{l}\text { Animal respiration takes at night and day, but } \\
\text { plant respiration takes only at night. } \\
\text { Because at day, plant absorbs } \mathrm{CO}_{2} \text { and } \\
\text { produces } \mathrm{O}_{2}, \text { while animal absorbs } \mathrm{O}_{2} \text { and } \\
\text { produces } \mathrm{CO}_{2} .\end{array}$ \\
3 & $\begin{array}{l}\text { Plant respiration absorbs } \mathrm{CO}_{2} \text { and produces } \\
\mathrm{O}_{2} \text {, otherwise, animal respiration absorbs } \mathrm{O}_{2} \\
\text { and produces } \mathrm{CO}_{2} .\end{array}$ \\
4 & $\begin{array}{l}\text { Respiration in plant uses } \mathrm{CO}_{2} \text { at day while } \\
\text { respiration in animal uses } \mathrm{O}_{2} \text { at day and night. }\end{array}$ \\
5 & $\begin{array}{l}\text { Plant produces } \mathrm{O}_{2} \text { at day and absorbs } \mathrm{O}_{2} \text { at } \\
\text { night, whereas, animals absorb } \mathrm{O}_{2} \text { at day and } \\
\text { night. }\end{array}$ \\
6 & $\begin{array}{l}\text { Respiration in plant needs sun light but that in } \\
\text { animal doesn't need it. } \\
\text { Respiration in plant takes place only at night } \\
\text { but all of the time for animals. } \\
\text { Respiration in animal produces energy but that } \\
\text { in plant doesn't produce it. }\end{array}$ \\
\hline 9 & $\begin{array}{l}\text { Respiration in plant means that it cooks food } \\
\text { but that in animal doesn't. }\end{array}$ \\
\hline 10 & $\begin{array}{l}\text { Animal can move but plant cannot. } \\
\text { Animal respires but plant does photosynthesis. } \\
\text { Respiration in plant needs a chlorophyll but it } \\
\text { doesn't in animal. }\end{array}$ \\
\hline 12 &
\end{tabular}

By looking at the students' explanations, they seemed unable to differentiate between photosynthesis and respiration in plants. They thought that photosynthesis in plants was the same as respiration because in photosynthesis the plants also absorbed and produced gas. This caused them to think that phenomena might be the same as taking a breath in animals. As they hold this concept firmly, their explanation about their decisions was based on it. For example, students thought respiration in plant needs chlorophyll but not in animal.

It seemed that they hold these wrong concepts firmly and consistently. When they met a new problem like question 1, as shown in the analysis of the question, only $8 \%$ from 624 students could make a right decision on the conditions that were right for photosynthesis, and only $9 \%$ of them could make a right decision on what conditions were right for respiration in plants. These misconceptions could obstruct students' thinking skills especially on various problems they might meet in future.

Another misconception found was that plant did not need to respire during the photosynthesis process. They concluded that respiration in plant only took place at night because during the day plant only carried photosynthesis. This misconception that found in 1996 was still exist in the present time. Keleş and Kefeli (2010) 
state that Biological phenomena, including photosynthesis and respiration, involve too many abstract concepts, which made students difficult to construct and structure the knowledge. Such difficulty became one of the factors that influenced the student's misconception. Moreover, the complexity of the concept and teacher's understanding also contributed to student's misconception. Based on the misconception diagnostic test given to the pre-service teacher from time to time, results found that the majority of pre-service teachers had misconceptions in photosynthesis. $56 \%$ of 90 pre-service teachers from 2010 until 2017 believed that green plant carried out photosynthesis in daytime and respiration at night time. The pre-service teachers gave a different reason for their answer that showed their perspective of photosynthesis and respiration (see Table 6).

Table 6. Pre-service Teachers' Reasons

\begin{tabular}{|c|c|}
\hline No & Explanation \\
\hline 1 & $\begin{array}{l}\text { Plant needs } \mathrm{CO}_{2} \text { at daytime for } \\
\text { photosynthesis and } \mathrm{CO}_{2} \text { at night, which is } \\
\text { released as a respiration product. }\end{array}$ \\
\hline 2 & $\begin{array}{l}\text { Photosynthesis and respiration did not happen } \\
\text { at the same time. }\end{array}$ \\
\hline 3 & $\begin{array}{l}\text { Photosynthesis takes place in chloroplast } \\
\text { while respiration takes place in mitochondria. }\end{array}$ \\
\hline 4 & $\begin{array}{l}\text { Photosynthesis happens at any time as long as } \\
\text { there is a light. }\end{array}$ \\
\hline 5 & $\begin{array}{l}\text { Respiration and photosynthesis in plant are } \\
\text { undertaken at the same time. }\end{array}$ \\
\hline 6 & $\begin{array}{l}\text { Plant will face difficulties if photosynthesis } \\
\text { and respiration happen at the same time } \\
\text { during the day because photosynthesis } \\
\text { requires } \mathrm{CO}_{2} \text { and respiration requires } \mathrm{O}_{2} \text {. }\end{array}$ \\
\hline 7 & $\begin{array}{l}\text { In plant, } \mathrm{O}_{2} \text { is released during the day and is } \\
\text { used at night. }\end{array}$ \\
\hline 8 & $\begin{array}{l}\text { Photosynthesis absolutely requires light and } \\
\text { the photolysis process of water produces } \mathrm{O} 2 \text {. }\end{array}$ \\
\hline 9 & $\begin{array}{l}\text { Plant can carry out photosynthesis and } \\
\text { respiration while animal only does } \\
\text { respiration. }\end{array}$ \\
\hline 10 & $\begin{array}{l}\text { Organelles that carry out photosynthesis and } \\
\text { respiration are different and performed in } \\
\text { separated processes }\end{array}$ \\
\hline 11 & $\begin{array}{l}\text { Plant absorbs oxygen at night so that it should } \\
\text { be put outside of the house. Meanwhile, } \\
\text { during the day it emits oxygen so that it can } \\
\text { be placed inside the house because it does not } \\
\text { compete with other organisms for oxygen } \\
\text { consumption. }\end{array}$ \\
\hline
\end{tabular}

In connection with Table 5, the pre-service teachers had misconception on photosynthesis and respiration in plant. They mostly experienced five misconceptions out of eleven given reasoning statements covering explanations $1,2,6,7$, and 11 . These misconceptions could be related to the common practice of many people in Indonesia who believed that plant should not be left indoors at night.

The results indicated that misconception in photosynthesis and respiration were already exist in preservice teachers from 2010 until 2017. The pre-conception in pre-service teachers' mind obtained from the previous Puji Jayanti, et al education level was one of the factors that affect the occurrence of the misconception. Pre-service teachers should be an important education agent because they would teach those the future generations. Their misconception might influence on their student's understanding and had a tendency to be transferred.

Misconception on respiration and photosynthesis in plant had been already happened since elementary school level. Laksana (2016) reports that, in elementary level, students had misconception about photosynthesis and respiration in plant. Those students believed that plant respired only at night because in the daytime it carried out photosynthesis. Such misconception existing in elementary level also occurred in junior high school level (Urey et al. 2018). Setiawati et al (2014) report that junior high school students had misconception on photosynthesis and those believed that plant carried out respiration at night since it could not get enough energy from photosynthesis.

Similar results were found that misconception about photosynthesis and respiration in plant still existed in junior high school students (Anjarsari, 2018). She also reports that the relation between photosynthesis and respiration was the most frequently investigated as misconceptions on science learning. Based on the review of several previous studies, there was a similar misconception existing in that past (study on misconception in 1996) and in the present time. The misconception that existed in junior high school was already exist in elementary school. It meant that elementary school students' misconception was continuously exist until they reached the higher education level namely in junior high school. It was also assumed that junior high school teachers were not successful to change the student's pre-conception.

From the teachers' explanations mentioned previously, generally there were two common errors of misconceptions about respiration in plant and in animal found, namely:

- $\quad$ Photosynthesis was similar to respiration in plants

- Plant's photosynthesis and respiration could not take place at the same time. In other words, when plant did photosynthesis, it could not perform respiration process.

Based on the results, it was found that the misconception on photosynthesis and respiration was still exist from times to times. There was a similar misconception experienced by junior high school students from 1996 to the present times. Consequently, it gave an awareness to the teachers that they should conduct better teaching and learning process on photosynthesis concept in future.

To be able to overcome the misconceptions, it is necessary to increase thinking skills, one of which is the ability of scientific reasoning. By using scientific reasoning, students will interpret information and find relevant evidence about the truth of the information by linking one concept to another. So students can evaluate whether the information they have gotten or the information they understand is true or false (Kambeyo, 2017)

In this case, scientific reasoning does not just appear but there must be training. Learning models that can train scientific reasoning skills are inquiry learning models (Blumer and Beck, 2019). By using inquiry 
learning students will be trained to carry out investigations aimed at finding the truth or answers to the problem.

. So in this case it is important to conduct further research on the development of inquiry-based learning devices to train scientific reasoning skills.

\section{CONCLUSION}

Based on the comparative study conducted by comparing misconceptions on photosynthesis and respiration experienced by junior high students in 1996 and that of the present times, this study concludes that:

1. There are similarities between misconception on photosynthesis and respiration experienced by students in 1996 and in the present times.

2. Common misconception that exists on photosynthesis and respiration concepts incudes: (1) Photosynthesis is the same as respiration in plant and (2) Plant's photosynthesis and respiration cannot take place at the same time. That is, when plant does photosynthesis, it cannot respire.

3. There are some misconceptions on photosynthesis and respiration experienced by pre-service teachers from 2010 until 2017.

4. Recommendations from this research are the need for scientific reasoning training to prevent misconceptions in the future and to change the misconceptions that occur.

5. Further research is needed to develop learning deviced that can train scientific reasoning skills. Scientific reasoning can be trained with inquiry learning.

\section{REFERENCES}

Anjarsari, P. (2018) The Common Science Misconceptions in Indonesia Junior High School Students. JSER 2018, 2(1), 21-24.

Bayuni, T. C., Sopandi, W., and Sujana, A. (2018). Identification misconception of primary school teacher education students in changes of matters using a five-tier diagnostic test. IOP Conf. Series: Journal of Physics: Conf. Series 1013 (2018) 012086

Blumer, L. S., and Beck, C. W. 2019. Laboratory Courses with Guided-Inquiry Modules Improve Scientific Reasoning and Experimental Design Skills for the LeastPrepared Undergraduate Students. CBE-Life Sciences Education, 18(1), ar2. doi:10.1187/cbe.18-08-0152

Kambeyo, L. (2017). Scientific Reasoning Skills: A Theoretical Background On Science Education. NERA Journal, Vol. 14, pp. 40-64.
Keleş, E., and Kefeli, P. (2010). Determination of student misconceptions in "photosynthesis and respiration" unit and correcting them with the help of cai material. Procedia-Social and Behavioral Sciences, 2 (2), 3111-3118.

Laksana, D. N. L. (2016). Miskonsepsi Dalam Materi IPA Sekolah Dasar. Jurnal Pendidikan Indonesia. Vol. 5, No. 2.

Parker, J. M., Anderson, C. W., Heidemann, M., Merrill, J., Merritt, B., Richmond, G., and Mark Urban-Lurain. (2012). Exploring Undergraduates' Understanding of Photosynthesis Using Diagnostic Question Clusters. CBE-Life Sciences Education Vol. 11, 47-57, Spring 2012.

Queloz A. Q., Klymkowsky, M. W., Stern, E., Hafen, E., Ko“hler, K. (2017). Diagnostic of students' misconceptions using the Biological Concepts Instrument (BCI): A method for conducting an educational needs assessment. PLoS ONE 12(5): e0176906.

Sadler, P. M., and Sonnert, G. (2016). Understanding Misconceptions: Teaching and Learning in Middle School Physical Science. American Educator. Spring. 2016.

Setiawati, G. A. D., Arjaya, I. B. A., \& Ekayanti, N. W. (2014). Identifikasi Miskonsepsi Dalam Materi Kelas Ix Smp Di Kota Denpasar. Jurnal Bakti Saraswati, 3(2), 1-15.

Suma, K., Sadia, I. W., and Pujani, N. M. (2017). The identification of the 11th grade students' prior knowledge of electricity concepts. IOP Conf. Series: Journal of Physics: Conf. Series 1040 (2018) 012038.

Svandova, K. (2014). Secondary School Students' Misconceptions about Photosynthesis and Plant Respiration: Preliminary Results. Eurasia Journal of Mathematics, Science \& Technology Education, 2014, 10(1), 59-67.

Urey, M. (2018). Defining the relationship between the perceptions and the misconceptions about photosynthesis topic of the preservice science teachers. European Journal of Educational Research, 7(4), 813-826.doi: 10.12973/eujer.7.4.813. 